\title{
A Study on the Planning Method of Temporary Residences for Refugees Following a Disaster - Focused on Korean Temporary Residences -
}

\author{
Jung-In Moon*1 and Sang-Ho Lee ${ }^{2}$ \\ ${ }^{1}$ Assistant Professor, Department of Interior Design, Kwandong University, Korea \\ ${ }^{2}$ Professor, Department of Architectural Engineering, Yonsei University, Korea
}

\begin{abstract}
The purpose of this study is to propose a planning method for forming a temporary residential complex, including temporary residences, administration and management, in order to evaluate the planning methods of temporary residential spaces for refugees. The study results are as follows: Even though a temporary residence is not a permanent structure, it must satisfy minimal housing standards. The characteristics of the temporary residential complex and residences are influenced by the temporary nature of the setting.

Therefore, complex location, arrangement planning, public and infrastructure facilities, which are the constituent elements of a temporary residential complex, must coincide with an appropriate residential location in Korea, including access to fresh water. And, the selection of an adequate housing area and the separation of each room according to residential function are needed for temporary residences. In addition, a prompt management system for a set time period, and a recycling plan must be developed for the managers and administrators.
\end{abstract}

Keywords: temporary residences; disaster; refugees; planning method

\section{Introduction}

\subsection{Background and purpose of the study}

The amount of damage due to natural disasters in Korea has been gradually increasing. Residential damage is especially great and, due to this, numerous refugees are either forced to wander or live in temporary accommodations since they cannot choose a place to go. In addition, since the housing situation for disaster victims is very poor, they use local facilities which can accommodate groups during the initial period following the disaster.

However, depending on the situation of those accommodations, the provision of a new temporary residence often becomes a necessity. Despite this, since there are no proper measures that have been provided for temporary residences, this lack of temporary residences has become a social problem.

Therefore the purpose of this study is to propose a planning method for the formation of a temporary residential complex, including residences, administration, and management by analyzing the characteristics of temporary residential complexes internationally as well as accessing residential spaces through on-site research and interviews in order to evaluate planning methods for temporary residences for refugees.

\footnotetext{
*Contact Author: Jung-In Moon, Assistant Professor,

Department of Interior Design, Kwandong University, 522 Naegokdong Gangnung-city Gangwon-do 210-701 Korea Tel: +82-33-649-7673 Fax: +82-33-642-7538

(Received April 6, 2007 ; accepted September 12, 2007)
}

\subsection{Scope of the study and methodology}

Documents were researched in order to study the background and developmental process of temporary residences. On-site research was performed to deduce the planning items in temporary residences and both surveys and interviews with staff members were conducted to make the planning for temporary residences more objective.

First, the concept of temporary residences was analyzed through the study of documents. The institutional mechanisms and problems of the developmental conditions of current temporary residences during a disaster were also analyzed.

Second, research of temporary residences through on-site research and interviews were also used in the analysis. The problems of domestic temporary residences and their improvement plans have been deduced by contrasting the on-site research of temporary residential complexes and temporary residences in Japan and Korea.

Third, the planning items of temporary residences were deduced after the staff members were interviewed and surveyed by forming planning items that were obtained through document and on-site research.

Fourth, planning methods for the administration and management of temporary residences and residential complexes have been proposed. 


\section{A Theoretical Consideration of Temporary Residences}

\subsection{The Concept of Temporary Residences during Disasters $^{1}$ and Calamities ${ }^{2}$}

The concept of housing space for the refugees of disasters refers to a temporary residence, with "temporary" being defined as not originally intended, not necessary, limited span of time before which formal measures can be taken, and "residence" referring to "a house or dwelling in which one lives," and also "the act or instance of living in a particular place." Therefore, the definitions of temporary and residence state of temporary residences are "houses built to accommodate persons only until they can find a permanent place to live." Because temporary residences includes the culture of those living within, we may say that temporary residences are an environment in which people can be accommodated until formal housing is found, in which housing is included. ${ }^{3}$

\subsection{Institutional Frameworks of Temporary Residences in Korea}

In Korea, despite damage, no adequate temporary residence supply solution was established, and as a result, victims were given containers as temporary residence units, as was the case in the past.

Also, in Clause 15 item 2 of the Architectural Law, temporary residence is defined only as "a temporary structure, the use of which is decided by presidential order," either in the disaster area or in surrounding areas, thereby stopping at merely designating the use of such facilities.

Additionally, because the accommodation facilities are decided through a series of steps by which the same governmental organizations are asked to cooperate with each other, the process of providing temporary residences becomes drawn out. Also, because of the irregular nature of natural disasters, these long and disorderly procedures make for inadequate legal measures. Therefore support for these solutions is also lacking, resulting in weak practical support for temporary residences.

In Japan, housing damage due to typhoon and earthquake often occurs and the size of damage is considerably greater than that of Korea. Accordingly, the administrative procedures for disaster occurrence and the system of temporary residence distribution are as follows: In the case of Japan, through the Ministry of Health, Labor and Welfare, and the Ministry of Land, Infrastructure and Transport, the Central Government plays a leading role and in the case of disaster occurrence, based on the Disaster Relief Act, the Ministry of Health, Labor and Welfare, with the jurisdiction of the proper budget makes a decision regarding the matter by request of the proper Prefectural entity. In addition, business concerning temporary residence is carried out by the main authority such as province, prefecture, Prefab Association and associated member construction companies. In this way, the division of labor in Japan between the bodies concerned is made on a systematic basis and has the merit of coping with disasters rapidly and precisely. To be concrete, temporary residence in Japan is provided in the form of a lease and in the case of a disaster; the Prefab Association with its branches placed in each district carries out the construction work of temporary residences by contracting construction companies located close to the disaster site.

\subsection{The Characteristics and Physical Components of Temporary Residences}

Temporary residences erected due to the occurrence of a disaster can be understood by the environmentally distinct innate characteristics and the circumstances surrounding it.

Therefore, temporary residences are temporary buildings as in Fig.1., but they must satisfy minimum housing standards. The characteristics of the residential complex and residence are decided upon under the premise that the situation is "temporary."

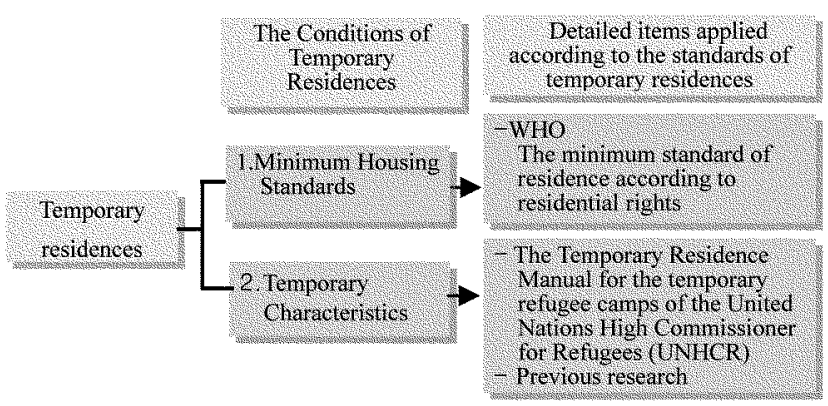

Fig.1. The Conditions of Temporary Residences

The characteristics of temporary residences can be divided into physical, social and cultural categories as in Table 1., and physical characteristics can be classified into the environmental and technical categories.

Table1. The Characteristics of Temporary Residences

\begin{tabular}{c|l|l}
\hline \multicolumn{2}{c|}{ Characteristics } & \multicolumn{1}{|c}{ Detailed Items } \\
\hline $\begin{array}{c}\text { Physical } \\
\text { Character } \\
\text { istics }\end{array}$ & $\begin{array}{l}\text { Environmental } \\
\text { Characteristics }\end{array}$ & $\begin{array}{l}\text { Safety, Hygiene, Convenience, Comfort, } \\
\text { Local Environment (climate, topography, } \\
\text { soil, water supply) }\end{array}$ \\
\hline $\begin{array}{c}\text { Technical } \\
\text { Characteristics }\end{array}$ & $\begin{array}{l}\text { Speed, mobility, light weight, modularity, } \\
\text { environmentally friendly } \\
\text { adjustability }\end{array}$ \\
\hline Characteristics
\end{tabular}

Additionally, the physical components forming a temporary residential complex were determined by applying the conditions of temporary residences in detail. Specifically, the section on the location and environment forming a temporary residential complex in the environmental index of the World Health Organization, and the concrete components of the complex location, the arrangement plan, the public facility, the foundation establishments, and the technical factors of temporary residences were derived from the temporary residences guide of the United 
Nations High Commissioner for refugees.

Therefore, classification of physical components forming temporary residences can be divided into the complex location, arrangement plans, public, infrastructure facilities, and temporary residences.

Additionally, it can be separated into six parts by adding the administration and management aspects derived from the research contents of the on-site research and interviews.

Table 2. The Physical Components of Temporary Residences

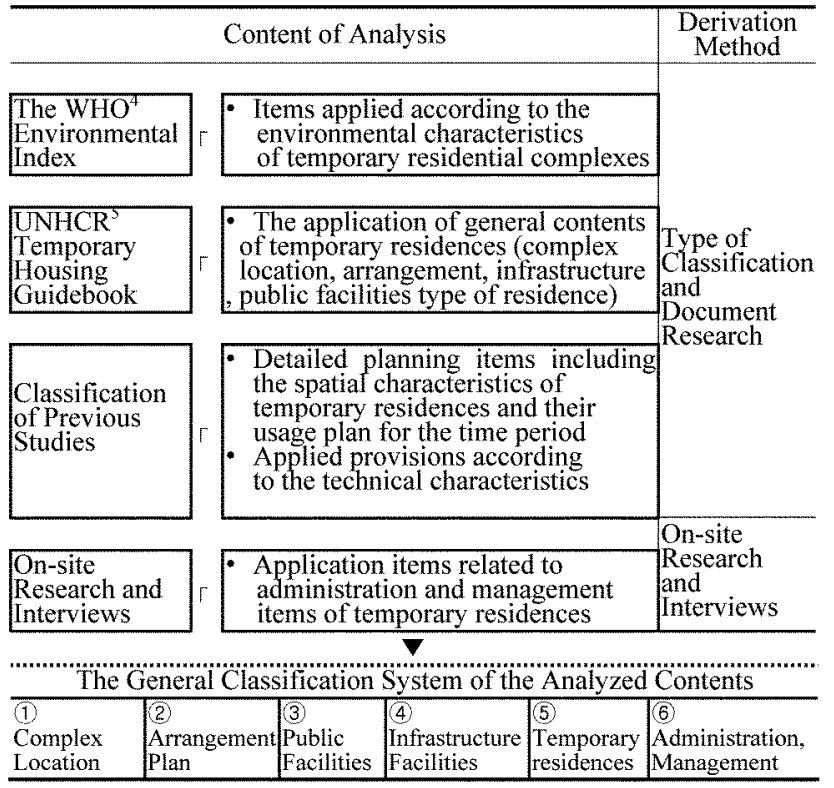

\section{Domestic and International On-Site Research on Temporary Residences \\ 3.1 Research Summary}

Table 3. Summary of On-site Research

\begin{tabular}{|c|c|c|c|c|c|}
\hline $\begin{array}{l}\text { Classif- } \\
\text { ication }\end{array}$ & Location & Type & Date & Period & $\begin{array}{l}\text { Research } \\
\text { Method }\end{array}$ \\
\hline Korea & $\begin{array}{l}\text { Sports Park, } \\
\text { Hajinbu 1-ri, } \\
\text { Pyeongchang-gun, } \\
\text { Hangye 2-ri, } \\
\text { Doeksan-ri, Garisan-ri, } \\
\text { Inje-gun, } \\
\text { Gangwon-do }\end{array}$ & Typhoon & $\begin{array}{l}2006 \\
7.15\end{array}$ & \begin{tabular}{|l}
2006 \\
9.1 \\
-9.20
\end{tabular} & \multirow{2}{*}{$\begin{array}{l}\text { On-Site } \\
\text { research } \\
\text { and } \\
\text { interviews } \\
\text { (Governm } \\
\text { ent official } \\
\text { in charge } \\
\text { and } \\
\text { resident } \\
\text { representa- } \\
\text { tive) }\end{array}$} \\
\hline Japan & $\begin{array}{l}\text { Ojiya Temporary } \\
\text { Residential } \\
\text { Complex } 1,2 \\
\text { Central Temporary } \\
\text { Residential Complex of } \\
\text { Nagaoka }\end{array}$ & Earthquake & $\begin{array}{l}2004 \\
10.23\end{array}$ & $\begin{array}{l}2006 \\
6.2 \\
\sim 7.1\end{array}$ & \\
\hline
\end{tabular}

This paper focuses on the planning method of temporary residences for refugees and in Korea, there have been no cases of providing temporary residence due to the occurrence of earthquakes; in most actual circumstances, temporary residence has instead been provided to the victims of a typhoon recently. Therefore, based on the specific character of the research, this paper focuses on analysis of the physical environment of temporary residences for disaster victims rather than on the type of disaster.

On-site research of temporary residences was performed domestically and internationally along with interviews in order to ascertain the items of the planning method of temporary residences that could not be extracted from researching documents.

Japan and Korea were selected as the locations for on-site research and interviews. Direct on-site research and interviews with the government officials in charge and residents were conducted as part of the research method. The details are shown in Table 3.

\subsection{On-site research and Interviews of Temporary Residences in Korea and Japan}

1) On-site research and Interviews in Korea

Empty vacant lots and existing residential areas were the preferred spaces for the complex location and in cases where the terrain was highly elevated there were problems with installing water drainage and other infrastructure facilities.

A form that could utilize outside space was preferred for the arrangement plan, and there were insufficient facilities in public facilities used as assembly rooms or management offices. Portable public restrooms, a waste disposal site, and so on have been installed as infrastructure facilities, and a shower room is used jointly.

Table 4. Contents of On-site Research in Korea

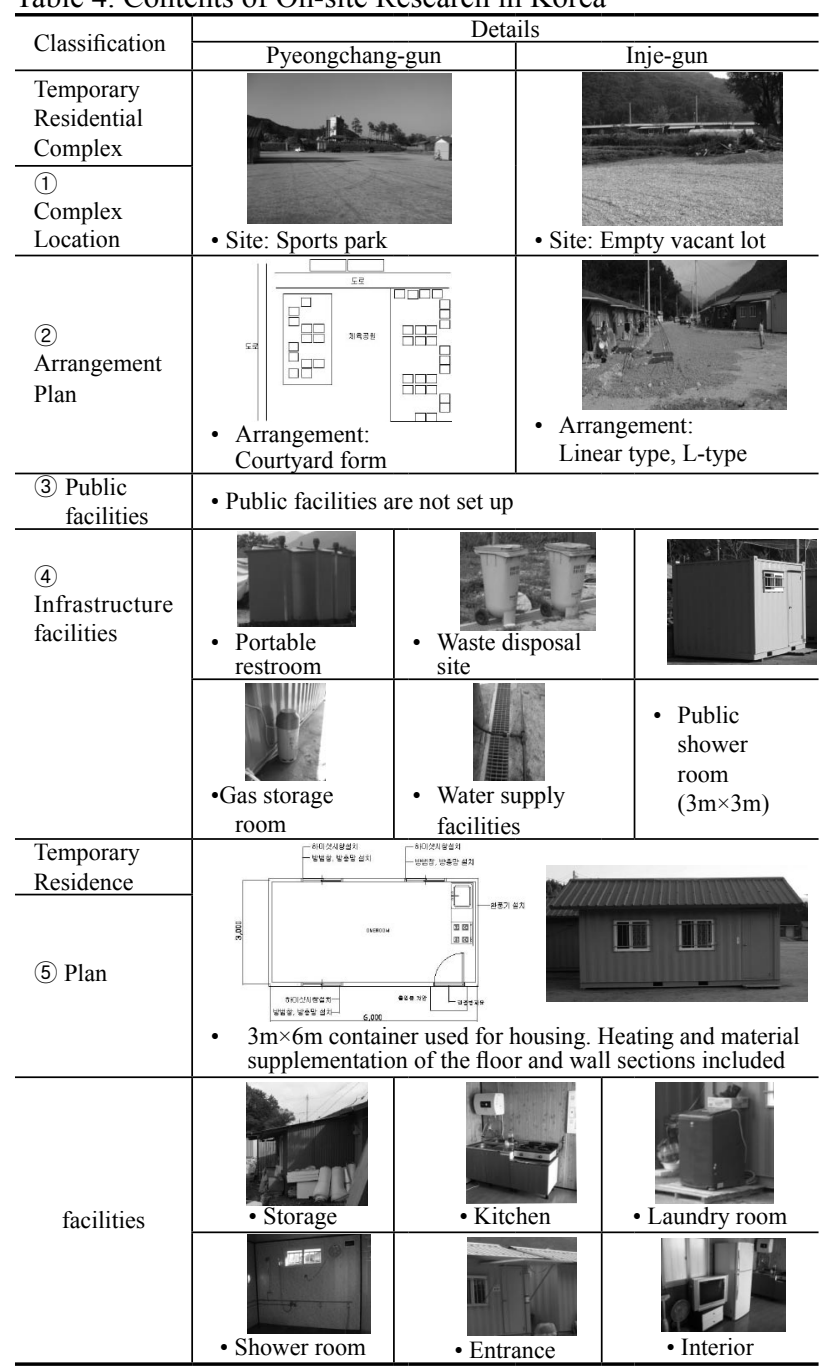


Table 5. Contents of Interviews in Korea

\begin{tabular}{|c|c|}
\hline \multirow{2}{*}{$\begin{array}{l}\text { Classi- } \\
\text { fication }\end{array}$} & Details \\
\hline & Pyeongchang-gun \\
\hline (1) & $\begin{array}{l}\text { - Most residents showed a preference for their existing place of } \\
\text { residence where a disaster broke out, as most of them are engaged in } \\
\text { agriculture. }\end{array}$ \\
\hline (2) & $\begin{array}{l}\text { - Residents favor the locational arrangement that makes use of } \\
\text { exterior space. }\end{array}$ \\
\hline (3) & $\begin{array}{l}\text { The refugees are scheduled to use the residence, which they should } \\
\text { leave sooner or later, until their permanent residence is provided. }\end{array}$ \\
\hline (4) & $\begin{array}{l}\text { - Inconvenience in using shower rooms due to the long distance from } \\
\text { their temporary housing. }\end{array}$ \\
\hline (5) & $\begin{array}{l}\text { - Inconvenience due to no available bathroom in the residence. } \\
\text { - Shortage of the storage system. } \\
\text { - The matter of condensation and bursting of pipes in freezing } \\
\text { weather. }\end{array}$ \\
\hline (6) & $\begin{array}{l}\text { - Administrative Process: there is difficulty in carrying out the } \\
\text { process due to insufficient guidance with respect to the provision } \\
\text { and supply of temporary residences. }\end{array}$ \\
\hline $\begin{array}{l}\text { Admin- } \\
\text { istration } \\
\text { and }\end{array}$ & $\begin{array}{l}\text { - Installation and Provision: one house }(3 \mathrm{~m} \times 6 \mathrm{~m}) \text { per family is } \\
\text { provided, accommodating an average of } 3 \sim 4 \text { people, and the weak } \\
\text { and elderly occupy about } 30 \% \text { of the total housing. }\end{array}$ \\
\hline $\begin{array}{l}\text { Manag } \\
\text { ement }\end{array}$ & $\begin{array}{l}\text { - Maintenance and Management: the local self-governing body } \\
\text { manages the facility and receives resident applications. }\end{array}$ \\
\hline & $\begin{array}{l}\text { - Usage plan for temporary residences: after use, the facility will be } \\
\text { sold to farmers for use as a storage facility. }\end{array}$ \\
\hline
\end{tabular}

The temporary residences were of a single type, regardless of the number of family members and only the kitchen facilities were installed inside. For details regarding temporary residence construction and administration, a manual is needed for the administrative process. The details are shown in Tables 4 . and 5.

2) On-site research and Interviews in Japan

The first complex location was a park in which infrastructure facilities were already installed and the second was a truck transfer site. The truck transfer site benefited from the use of convenient, pre-existing transportation and facilities.

The residences were organized in a linear-type

Table 6. Contents of On-site Research in Japan

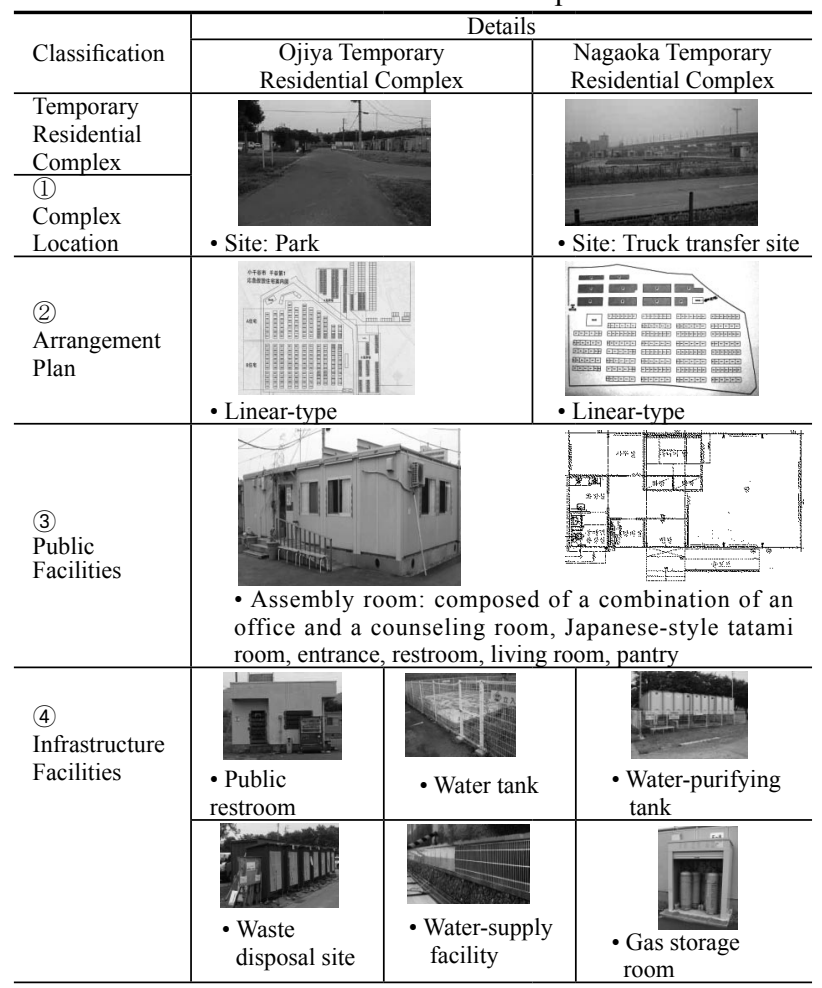

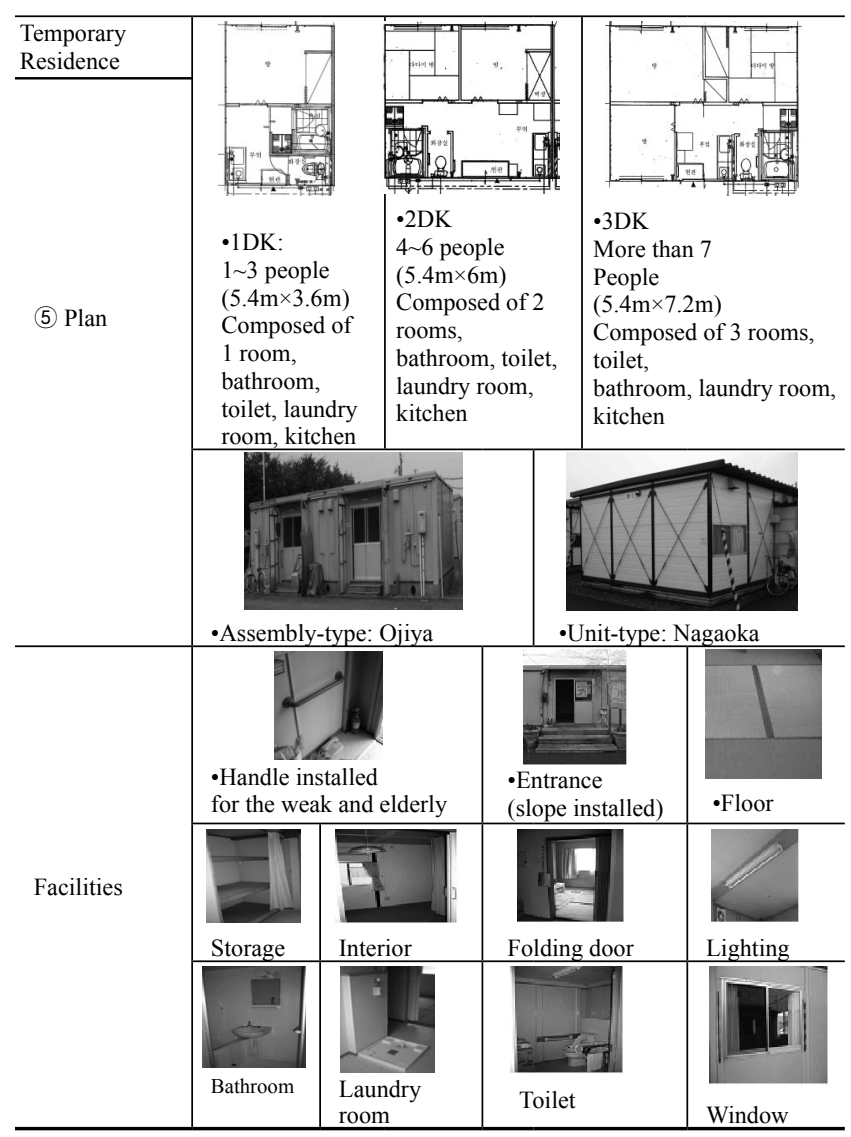

Table 7. Contents of Interviews in Japan

\begin{tabular}{|c|c|c|}
\hline \multirow{2}{*}{$\begin{array}{l}\text { Classif- } \\
\text { ication }\end{array}$} & \multicolumn{2}{|c|}{ Details } \\
\hline & $\begin{array}{c}\text { Ojiya Temporary } \\
\text { Residential Complex }\end{array}$ & $\begin{array}{l}\text { Nagaoka Temporary } \\
\text { Residential Complex }\end{array}$ \\
\hline (1) & \multicolumn{2}{|c|}{ - Preference for a location close to the existing abode. } \\
\hline (2) & \multicolumn{2}{|c|}{ - At time of arranging locations, keep intervals between for climate. } \\
\hline (3) & \multicolumn{2}{|c|}{-An assembly place is arranged for more than or less than 50 housings. } \\
\hline (4) & \multicolumn{2}{|c|}{ - Shutdown of the public restroom resulted from low frequency. } \\
\hline (5) & \multicolumn{2}{|c|}{$\begin{array}{l}\text { - Occurrence of leakage in the ceilings and condensation on the walls } \\
\text { - Malfunction of drainage } \\
\text { - Insufficiency in proper counter-measures concerning the climate. }\end{array}$} \\
\hline & \multicolumn{2}{|c|}{$\begin{array}{l}\text { - Administrative Process: the manual is a sketch provided by the Prefab } \\
\text { Association and speed is the most important factor, Necessity of } \\
\text { making policies on evacuation due to the difficulty in reflecting the } \\
\text { residents' opinions. }\end{array}$} \\
\hline $\begin{array}{l}\text { Admin- } \\
\text { istration } \\
\text { and }\end{array}$ & \multicolumn{2}{|c|}{$\begin{array}{l}\text { - Installation and Proposal: Usually when deciding Ministry of Heath, } \\
\text { labor and Welfare matters, the Prefab Architect's Society, made up of } \\
\text { Prefab manufacturers and each district install the facility after signing } \\
\text { an agreement. }\end{array}$} \\
\hline & \multicolumn{2}{|c|}{$\begin{array}{l}\text { - Building management method: Acts in consultation with the Prefab } \\
\text { Association. }\end{array}$} \\
\hline & \multicolumn{2}{|c|}{$\begin{array}{l}\text { - Usage plan of temporary residences: Used as relief residences during } \\
\text { other disasters through disassembly and export overseas. }\end{array}$} \\
\hline
\end{tabular}

module arrangement so that the transfer route is concise and clear. An assembly room, common room, senior center, and other rooms were created in public facilities, and storage spaces such as offices were installed inside them. Infrastructure facilities include a water-purifying tank, a water tank, public restrooms, a recycling site and a gas storage room, and regarding the arrangement characteristic, the transfer route and location selection are clearly marked to reflect the specific qualities of temporary facilities.

There are both assembly and unit-types for the temporary residences, and there are three ground plans including $1 \mathrm{~K}, 2 \mathrm{DK}$ and $3 \mathrm{DK}$, with the room, toilet, and bathrooms separated according to the minimal residential standards, and a transfer route 
is clearly planned for each room. The administrative process, selection standards for residents, and their arrangement occurred quickly for the administration and management, and the residences were installed, provided, and maintained by the Prefab Association. The details are shown in Tables 6 . and 7.

3) Comparison of on-site research and Interviews of Temporary Residences in Korea and Japan

Table 8. Comparison of On-site Research and Interviews of Temporary Residences in Korea and Japan

\begin{tabular}{|c|c|c|c|c|}
\hline \multirow[b]{2}{*}{ Classification } & \multirow{2}{*}{\multicolumn{2}{|c|}{\begin{tabular}{|l|} 
Japan \\
Earthquake in October, \\
2004 \\
\end{tabular}}} & \multicolumn{2}{|c|}{ Korea } \\
\hline & & & \multicolumn{2}{|c|}{ Typhoon on July 15, 2006} \\
\hline $\begin{array}{l}\text { Location } \\
\text { selection }\end{array}$ & \multicolumn{2}{|c|}{$\begin{array}{l}\text { - Land type with } \\
\text { satisfactory approachability } \\
\text { and good } \\
\text { water drainage. }\end{array}$} & \multicolumn{2}{|c|}{$\begin{array}{l}\text { - Preference for existing } \\
\text { residential areas. } \\
\text { - Took into account the form of } \\
\text { each group and } \\
\text { individual }\end{array}$} \\
\hline $\begin{array}{l}\text { Arrangement } \\
\text { plan }\end{array}$ & \multicolumn{2}{|c|}{$\begin{array}{l}\text { - Arranged according to the } \\
\text { distance between buildings and } \\
\text { road system for } \\
\text { efficient goods services. }\end{array}$} & \multicolumn{2}{|c|}{$\begin{array}{l}\text { - Linear-type arrangement } \\
\text { (courtyard form) } \\
\text { - In need of a detailed } \\
\text { arrangement plan. }\end{array}$} \\
\hline Public facility & \multicolumn{2}{|c|}{$\begin{array}{l}\text { - Assembly room and } \\
\text { common room. }\end{array}$} & \\
\hline \multirow{6}{*}{$\begin{array}{l}\text { Infrastructure } \\
\text { facilities }\end{array}$} & $\begin{array}{l}\text { 1. Public } \\
\text { restroom }\end{array}$ & $\begin{array}{l}\text { Main complex } \\
\text { entrance }\end{array}$ & $\begin{array}{l}\text { 1. Public } \\
\text { restroom }\end{array}$ & $\begin{array}{l}\text { Arranged by } \\
\text { number of } \\
\text { temporary } \\
\text { residences }\end{array}$ \\
\hline & $\begin{array}{l}\text { 2. Water- } \\
\text { purifying } \\
\text { tank }\end{array}$ & $\begin{array}{l}\text { Separate from } \\
\text { the complex }\end{array}$ & $\begin{array}{l}\text { 2. Water- } \\
\text { purifying } \\
\text { tank }\end{array}$ & - \\
\hline & $\begin{array}{l}\text { 3. Water } \\
\text { tank }\end{array}$ & $\begin{array}{l}\text { Separate from } \\
\text { the complex }\end{array}$ & 3. Water tank & - \\
\hline & \begin{tabular}{|l|}
$\begin{array}{l}\text { 4. Waste } \\
\text { disposal } \\
\text { site }\end{array}$ \\
\end{tabular} & $\begin{array}{l}\text { At the main } \\
\text { complex } \\
\text { entrance }\end{array}$ & $\begin{array}{l}\text { 4. Waste } \\
\text { disposal site }\end{array}$ & $\begin{array}{l}\text { Main complex } \\
\text { entrance }\end{array}$ \\
\hline & \multirow{2}{*}{$\begin{array}{l}\text { 5. Gas } \\
\text { storage } \\
\text { room }\end{array}$} & \multirow{2}{*}{$\begin{array}{l}\text { Arranged at } \\
\text { the end of } \\
\text { block }\end{array}$} & $\begin{array}{l}\text { 5. Gas } \\
\text { storage }\end{array}$ & - \\
\hline & & & $\begin{array}{l}\text { 6. Shower } \\
\text { room }\end{array}$ & $\begin{array}{l}\text { Center of } \\
\text { complex }\end{array}$ \\
\hline $\begin{array}{l}\text { Temporary } \\
\text { residence }\end{array}$ & \multicolumn{2}{|c|}{$\begin{array}{l}\text { *1DK }\left(1 \sim 3 \text { people, } 19.5 \mathrm{~m}^{2}\right) \\
\text { *2DK }\left(4 \sim 6 \text { people, } 32.4 \mathrm{~m}^{2}\right) \\
\text { *3DK } \\
\left.\text { (over } 7 \text { people, } 38.9 \mathrm{~m}^{2}\right) \\
\text { - Two types including } \\
\text { unit and assembly type } \\
\text { - Station a toilet, bathroom, } \\
\text { laundry room and facilities for } \\
\text { the disabled, weak, and elderly } \\
\text { indoors. }\end{array}$} & \multicolumn{2}{|c|}{$\begin{array}{l}\text { * } 3 \mathrm{~m} \times 6 \mathrm{~m} \\
\left(18 \mathrm{~m}^{2}, \text { average of }\right. \\
3 \text { people reside }) \\
\text { - Includes kitchen facilities } \\
\text { only. } \\
\text { - No bathroom, or laundry } \\
\text { room. } \\
\text { - Made for storage, so is hot } \\
\text { in the summer and cold in } \\
\text { the winter. }\end{array}$} \\
\hline $\begin{array}{l}\text { Administra- } \\
\text { tive } \\
\text { process }\end{array}$ & \multicolumn{2}{|c|}{$\begin{array}{l}\text { Managed based on the } \\
\text { Ministry of Heath labor, } \\
\text { and Welfare guide. }\end{array}$} & \multicolumn{2}{|c|}{$\begin{array}{l}\text { - Based on the Natural } \\
\text { Disaster Research and } \\
\text { Restoration Plan } \\
\text { Establishment Guide, but } \\
\text { there is no guide related to } \\
\text { temporary residences. }\end{array}$} \\
\hline $\begin{array}{l}\text { Installment } \\
\text { Maintenance } \\
\text { Management }\end{array}$ & \multicolumn{2}{|c|}{$\begin{array}{l}\text { - Is installed, maintained } \\
\text { and managed by the } \\
\text { Prefab Association } \\
\text { when the city requests it. }\end{array}$} & \multicolumn{2}{|c|}{$\begin{array}{l}\text { An official of the local } \\
\text { self-governing body orders } \\
\text { a business to install, } \\
\text { maintain and manage it. }\end{array}$} \\
\hline Period & \multicolumn{2}{|l|}{ - 2 years } & \multicolumn{2}{|l|}{ - 6 months } \\
\hline Usage plan & \multicolumn{2}{|c|}{$\begin{array}{l}\text { - Situation after } \\
\text { complete restoration: } \\
\text { Components recycled, used } \\
\text { for aid, or exported } \\
\text { overseas }\end{array}$} & \multicolumn{2}{|c|}{$\begin{array}{l}\text { - Situation after complete } \\
\text { restoration: } \\
\text { Public sale treatment } \\
\text { subject to ordinary people. }\end{array}$} \\
\hline
\end{tabular}

When comparing the temporary residences of Korea and Japan, the need for reform in Korean temporary residences is clear. Specifically, the greatest problem for Korean temporary residences is planning and administration, maintenance and management.

Since the average Korean temporary residence is of a single type, in which there are no separate rooms inside the shelter, there is a demand to accommodate the need for variation in the form of temporary residences.
In addition, the administrative process, maintenance and management need to be rationally systematized. Therefore, flexibility in the planning, design and technological development of temporary residences must be promoted. Furthermore the development of construction, materials and component technology is also necessary. Finally, there is also a need to research a method for reusing temporary residences. The details are shown in Table 8.

\section{Derivation of Planning Items for Temporary Residences \\ 4.1 Outline for the Derivation of Planning Items for Temporary Residences}

The process of determining the planning items of temporary residences for refugees involves 3 main steps as shown in Fig.2.

In step 1, the planning items forming the physical environment of temporary residences are established through a theoretical study. In step 2, the planning items for habitability, administration and management are given priority according to on-site research and interviews after visiting actual temporary residential complexes within Korea and Japan. Step 3 consisted of a staff survey. These results were used to more objectively reorganize the planning items that were derived through the process above.

\begin{tabular}{c} 
Step 1 \\
$\begin{array}{c}\text { Document } \\
\text { research }\end{array}$ \\
\hline
\end{tabular}

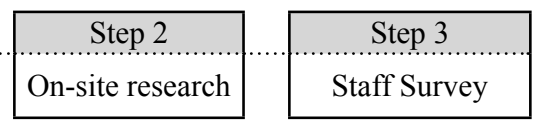

Fig.2. Outline for the Determination of Planning Items for Temporary Residences

\subsection{Determination of Planning Items for Temporary Residences}

1) The reorganization of planning items for temporary residences through documentation and on-site research (steps 1,2)

Step 1 to step 2 is the examination process of temporary residence planning items, which is divided into three steps as shown in Table 9.

Firstly, this process is important because it highlights the items that overlapped in the documentation, and on-site research as well as the interviews. Secondly, content regarding the improvement of domestic temporary residences derived from the comparison of actual sites in Korea and Japan is ordered according to priority. Thirdly, inadequate items have been excluded and reorganized according to a method combining factors with similar purposes that appear in both the document and on-site researches. This method combines these redundant items into identical factors and reorganizes them into a method of planning the physical environment.

2) Analysis of the importance of planning items for temporary residences through a staff survey (step 3)

The staff survey was conducted from September 
Table 9. Reorganization of Planning Items for Temporary Residences through Documentation and On-site Research

\begin{tabular}{|c|c|c|}
\hline $\begin{array}{l}\text { General } \\
\text { Classifi- } \\
\text { cation }\end{array}$ & $\begin{array}{c}\text { Detailed } \\
\text { Classification }\end{array}$ & Planning Items applied in detail \\
\hline \multirow{8}{*}{$\begin{array}{l}\text { Complex } \\
\text { location }\end{array}$} & Complex size & $\begin{array}{l}\text { (1) A complex with an adequate number of } \\
\text { residences that satisfy the minimal } \\
\text { residence area. }\end{array}$ \\
\hline & \multirow{6}{*}{$\begin{array}{l}\text { Location } \\
\text { selection }\end{array}$} & $\begin{array}{l}\text { (2) An area close to a major road with a } \\
\text { satisfactory resource approach. }\end{array}$ \\
\hline & & $\begin{array}{l}\text { (3) An area in which empty vacant lots can be } \\
\text { secured simultaneously with the } \\
\text { occurrence of a disaster. }\end{array}$ \\
\hline & & $\begin{array}{l}\text { (4) An area close to the pre-existing } \\
\text { residence. }\end{array}$ \\
\hline & & $\begin{array}{l}\text { (5) A location in which there is convenient } \\
\text { transportation and communication at the } \\
\text { time of land selection. }\end{array}$ \\
\hline & & (6) A location safe from disasters. \\
\hline & & $\begin{array}{l}\text { (7) A location with safe levels of noise, water } \\
\text { quality and water supply. }\end{array}$ \\
\hline & Topography & $\begin{array}{l}\text { 8) A topography in which basic facilities } \\
\text { can be built and which has an } \\
\text { adequate water supply. }\end{array}$ \\
\hline \multirow{4}{*}{$\begin{array}{l}\text { Arrange- } \\
\text { ment Plan }\end{array}$} & \multirow[b]{2}{*}{$\begin{array}{l}\text { Temporary } \\
\text { Residences }\end{array}$} & $\begin{array}{l}\text { (1) Efficient arrangement following a } \\
\text { module method. }\end{array}$ \\
\hline & & $\begin{array}{l}\text { (2) Arranged by setting the distance between } \\
\text { buildings according to the characteristics } \\
\text { of the district and climate. }\end{array}$ \\
\hline & $\begin{array}{l}\text { Infrastructure } \\
\text { public facilities }\end{array}$ & $\begin{array}{l}\text { (3) Infrastructure facilities and public } \\
\text { facilities are arranged in concentration, } \\
\text { according to the characteristic that they } \\
\text { are temporary. }\end{array}$ \\
\hline & $\begin{array}{l}\text { Traffic line } \\
\text { system }\end{array}$ & $\begin{array}{l}\text { (4) A concise and clear transfer route plan, } \\
\text { for the efficient transportation of relief } \\
\text { materials and vehicle transfer during } \\
\text { disaster emergencies. }\end{array}$ \\
\hline \multirow{4}{*}{$\begin{array}{l}\text { Public } \\
\text { Facilities }\end{array}$} & Type & (1) Types of public facility. \\
\hline & Location & $\begin{array}{l}\text { (2) Located in the center at the entrance of } \\
\text { the complex, which can be seen from } \\
\text { anywhere in the complex and is a similar } \\
\text { distance away from each residence. }\end{array}$ \\
\hline & Kinds & $\begin{array}{l}\text { (3) Self government management office, } \\
\text { assembly room and sales facilities. }\end{array}$ \\
\hline & $\begin{array}{l}\text { Number and } \\
\text { arrangement }\end{array}$ & $\begin{array}{l}\text { (4) An adequate number of public facilities } \\
\text { according to the number of houses, and } \\
\text { closely positioned to residences. }\end{array}$ \\
\hline \multirow{4}{*}{$\begin{array}{l}\text { Infra- } \\
\text { structure } \\
\text { Facilities }\end{array}$} & $\begin{array}{c}\text { Sanitary } \\
\text { arrangements }\end{array}$ & $\begin{array}{l}\text { (1) Facility installment for uninterrupted } \\
\text { water drainage and distribution for a } \\
\text { sanitary environment. }\end{array}$ \\
\hline & $\begin{array}{l}\text { Public } \\
\text { sanitation }\end{array}$ & $\begin{array}{l}\text { (2) Install facilities that can be easily } \\
\text { constructed and removed, according to the } \\
\text { toilet or public bathroom installation. }\end{array}$ \\
\hline & $\begin{array}{c}\text { Waste disposal } \\
\text { site }\end{array}$ & $\begin{array}{l}\text { (3) The location and site of the waste disposal } \\
\text { site. }\end{array}$ \\
\hline & $\begin{array}{l}\text { Gas storage } \\
\text { room }\end{array}$ & $\begin{array}{l}\text { (4) The installation of a collective gas storage } \\
\text { room, which takes into account } \\
\text { convenience and safety for cooking. }\end{array}$ \\
\hline \multirow[b]{14}{*}{$\begin{array}{l}\text { Temporary } \\
\text { Residence }\end{array}$} & \multirow{5}{*}{ Plan } & $\begin{array}{l}\text { (1) Corresponds to the minimal residential } \\
\text { size. }\end{array}$ \\
\hline & & $\begin{array}{l}\text { (2) Types according to the number of family } \\
\text { members. }\end{array}$ \\
\hline & & $\begin{array}{l}\text { (3) The separation of rooms according to the } \\
\text { minimal residential function. }\end{array}$ \\
\hline & & (4) The alterability of space. \\
\hline & & $\begin{array}{l}\text { (5) The standardization of units to ease space } \\
\text { formation. }\end{array}$ \\
\hline & \multirow{2}{*}{$\begin{array}{l}\text { Elevation, } \\
\text { section plan }\end{array}$} & $\begin{array}{l}\text { 6) The functional reflections of the window, } \\
\text { entrance and roof are used as elevation } \\
\text { factors. }\end{array}$ \\
\hline & & $\begin{array}{l}\text { (7) A rational plan for the height of the } \\
\text { ceiling as a characteristic of a structure in } \\
\text { which movement is possible. }\end{array}$ \\
\hline & \multirow[b]{2}{*}{$\begin{array}{l}\text { Construction } \\
\text { Plan }\end{array}$} & (8) Fixed type, portable type. \\
\hline & & $\begin{array}{l}\text { (9) Fit for the standards of the structure and } \\
\text { equipment according to the local climate. }\end{array}$ \\
\hline & \multirow{3}{*}{ Material Plan } & (10) A material plan in which reuse is possible. \\
\hline & & $\begin{array}{l}\text { (11) A plan using the local material } \\
\text { (environment-friendly). }\end{array}$ \\
\hline & & $\begin{array}{l}\text { (12) A light material plan taking into account } \\
\text { mobility (light weight). }\end{array}$ \\
\hline & \multirow{2}{*}{$\begin{array}{l}\text { Electric } \\
\text { equipment }\end{array}$} & $\begin{array}{l}\text { (13) Install facilities appropriate to climate } \\
\text { (condensation and water leakage). }\end{array}$ \\
\hline & & $\begin{array}{l}\text { (14) Provide equipment for cooling and } \\
\text { heating. }\end{array}$ \\
\hline
\end{tabular}

\begin{tabular}{l|c|c}
\hline \multirow{2}{*}{$\begin{array}{l}\text { Temporary } \\
\text { Residence }\end{array}$} & $\begin{array}{c}\text { Interior } \\
\text { planning }\end{array}$ & $\begin{array}{c}\text { (15) Install facilities for the weak and elderly } \\
\text { and storage furniture indoors. }\end{array}$ \\
\cline { 2 - 3 } & $\begin{array}{c}\text { Installment } \\
\text { time }\end{array}$ & (16) A short time period. \\
\hline \multirow{4}{*}{$\begin{array}{c}\text { Admini- } \\
\text { stration } \\
\text { and } \\
\text { Manage- } \\
\text { ment }\end{array}$} & $\begin{array}{c}\text { Administra- } \\
\text { tive process }\end{array}$ & $\begin{array}{c}\text { 1) The need for a rapid and detailed manual } \\
\text { following the installment and proffer of } \\
\text { temporary residences. }\end{array}$ \\
\cline { 2 - 3 } & $\begin{array}{c}\text { Maintenance } \\
\text { management }\end{array}$ & $\begin{array}{c}\text { (3) A close organizational system with a } \\
\text { company that can install in a short time. } \\
\text { system between the residents and the } \\
\text { official in charge of administrative work. }\end{array}$ \\
\cline { 2 - 3 } & Proposal period & $\begin{array}{c}\text { 4) A flexible plan divided into before living } \\
\text { in a permanent residence, a short time, a } \\
\text { medium amount of time, and a long time. }\end{array}$ \\
\cline { 2 - 3 } & Usage plan & $\begin{array}{c}\text { 5) A plan to utilize it for other purposes, and } \\
\text { to recycle. }\end{array}$ \\
\hline
\end{tabular}

18 , to October 21,2006 , in which the survey items consisted of 8 for the arrangement plan; 4 for public facilities; 6 for infrastructure facilities; 16 for temporary residence and 5 for the administration and management sector, totaling 43 items out of the six grand classifications. In addition, the survey questionnaires were collected from each organization by visit in person and 70 appropriate copies were collected out of the already distributed 78 copies.

The staff survey members in charge of the temporary residences are, specifically, officials in charge of temporary residences in the Korean Institute of Female Architects, the Housing Team at the Disaster Relief, and the National Emergency Management Agency.

The survey was composed of closed Likert Scale questions. A SPSS10.0 Windows version of the collected data was used, while a multiple regression analysis was used as the main statistical method for the analysis of the staff survey. The details are shown in Table 10.

Table 10. Staff Survey General Items

\begin{tabular}{|c|c|c|c|c|c|}
\hline \multirow{2}{*}{$\begin{array}{l}\text { Occup- } \\
\text { ational } \\
\text { Classif- } \\
\text { ication }\end{array}$} & $\begin{array}{l}\text { Research } \\
\text { institute }\end{array}$ & $\begin{array}{l}\text { Admini- } \\
\text { strative } \\
\text { machinery }\end{array}$ & $\begin{array}{l}\text { Archi- } \\
\text { tectural } \\
\text { office }\end{array}$ & $\begin{array}{l}\text { Construc- } \\
\text { tion } \\
\text { company }\end{array}$ & Total \\
\hline & $\begin{array}{c}5 \\
(7.1 \%) \\
\end{array}$ & $\begin{array}{c}52 \\
(74.3 \%) \\
\end{array}$ & $\begin{array}{c}10 \\
(14.3 \%) \\
\end{array}$ & $\begin{array}{c}3 \\
(4.3 \%) \\
\end{array}$ & $\begin{array}{c}70 \\
(100 \%) \\
\end{array}$ \\
\hline \multirow[b]{2}{*}{ Careers } & 5 years & $6-10$ years & $\begin{array}{l}11-15 \\
\text { years }\end{array}$ & $\begin{array}{l}15-21 \\
\text { years }\end{array}$ & Total \\
\hline & $\begin{array}{c}13 \\
(18.6 \%) \\
\end{array}$ & $\begin{array}{c}20 \\
(28.6 \%) \\
\end{array}$ & $\begin{array}{c}22 \\
(31.4 \%) \\
\end{array}$ & $\begin{array}{c}15 \\
(21.4 \%) \\
\end{array}$ & $\begin{array}{c}70 \\
(100 \%) \\
\end{array}$ \\
\hline \multirow[b]{2}{*}{ Years } & Twenty & Thirty & Forty & Fifty & Total \\
\hline & $\begin{array}{c}9 \\
(12.9 \%)\end{array}$ & $\begin{array}{c}36 \\
(51.4 \%)\end{array}$ & $\begin{array}{c}19 \\
(27.1 \%) \\
\end{array}$ & $\begin{array}{c}6 \\
(8.6 \%)\end{array}$ & $\begin{array}{c}70 \\
(100 \%) \\
\end{array}$ \\
\hline
\end{tabular}

As a result of multiple regression analysis, items on the 'Satisfactory Resource Approach' and 'Convenient Transportation and Communication' have been derived in the complex location planning area. In terms of the arrangement plan, items such as 'Traffic Line System and 'Arrangement of Infrastructure Public Facilities have been deduced.

The location and type of public facility in the planning area, the contents of public sanitation, the waste disposal site, and the storage room in the infrastructure facilities planning area have been determined to be the important items that have been affected. Additionally, the separation of rooms according to residential function, installment of facilities for the weak and elderly and contents that must be installed in a short time in the temporary 
Table 11. Results of Multiple Regression Analysis

\begin{tabular}{|c|c|c|c|c|c|}
\hline \multirow{2}{*}{ Classification } & \multirow{2}{*}{ Evaluated Item } & \multicolumn{2}{|c|}{ 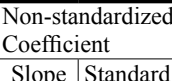 } & $\begin{array}{l}\text { Standardized } \\
\text { Coefficient }\end{array}$ & \multirow{2}{*}{ T Value } \\
\hline & & \begin{tabular}{|c|} 
Slope \\
(B)
\end{tabular} & \begin{tabular}{|c|} 
Standard \\
Error
\end{tabular} & Beta & \\
\hline \multirow[b]{2}{*}{ Complex Location } & $\begin{array}{l}\text { (2) Satisfactory } \\
\text { resource } \\
\text { approach }\end{array}$ & .431 & .113 & $.396 * \star$ & 3.555 \\
\hline & $\begin{array}{l}\text { (5) Convenient } \\
\text { transportation } \\
\text { and } \\
\text { communication }\end{array}$ & .460 & .121 & 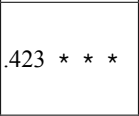 & 3.792 \\
\hline \multirow[t]{2}{*}{ Arrangement Plan } & $\begin{array}{l}\text { (3) Arrangement of } \\
\text { infrastructure and } \\
\text { public facilities }\end{array}$ & .217 & .109 & $.218 *$ & 3.926 \\
\hline & $\begin{array}{l}\text { (4) A Concise } \\
\text { traffic line system }\end{array}$ & .467 & .101 & $.508 * \star \star$ & 1.993 \\
\hline \multirow{2}{*}{ Public Facilities } & (2) Location & .222 & .077 & $.538 \star \star$ & 2.884 \\
\hline & (3) Type & .538 & .098 & $.284 * \star \star$ & 5.470 \\
\hline \multirow{3}{*}{$\begin{array}{l}\text { Infrastructure } \\
\text { Facilities }\end{array}$} & (2) Public sanitation & .377 & .093 & $.436 * \star \star$ & 4.061 \\
\hline & (3) Waste disposal & .290 & .104 & $.299 \star \star$ & 2.787 \\
\hline & (4) Gas storage room & .230 & .134 & $.258 *$ & 2.367 \\
\hline \multirow{3}{*}{$\begin{array}{l}\text { Temporary } \\
\text { Residence }\end{array}$} & $\begin{array}{l}\text { (3) Differentiation } \\
\text { of rooms }\end{array}$ & .316 & .116 & $.310 \star$ & 2.660 \\
\hline & $\begin{array}{l}\text { (15) Facilities for the } \\
\text { weak and elderly } \\
\end{array}$ & .350 & .114 & $.358 \star \star$ & 3.068 \\
\hline & $\begin{array}{l}\text { (16) Short time } \\
\text { installment }\end{array}$ & .317 & .119 & $.311 \star$ & 2.669 \\
\hline \multirow{3}{*}{$\begin{array}{l}\text { Administration } \\
\text { and } \\
\text { Management }\end{array}$} & $\begin{array}{l}\text { (1) Administrative } \\
\text { process }\end{array}$ & .274 & .083 & $.248 *$ & 2.134 \\
\hline & $\begin{array}{l}\text { (2) Installment } \\
\text { Proposal }\end{array}$ & .313 & .137 & $.265 *$ & 3.285 \\
\hline & $\begin{array}{l}\text { (3) Maintenance } \\
\text { and management }\end{array}$ & .422 & .128 & $.382 \star *$ & 2.283 \\
\hline
\end{tabular}

* : $\mathrm{P}<0.05, * *: \mathrm{P}<0.01, * * *: \mathrm{P}<0.001$

residence planning area, have been identified as items requiring attention. The administrative process, installment and proposal, and maintenance and management have been identified as items requiring attention in the administration and management planning area.

\section{Proposal of the Planning Method for Temporary} Residences

\subsection{Outline for the Planning Method of Temporary Residences}

The planning items are not planned independently from each other but through a collective mutual relationship, and are provided as a temporary residential space as a whole. Important items deduced through the staff survey can be used as one of the important indexes, since it was an evaluation by the staff, however, it cannot be said to be a comprehensive method for deriving all of the planning items for a temporary residence. Therefore based on this, a corresponding temporary residence planning method for refugees was based on planning items that can be applied in Korea by reorganizing the contents of document and on-site research. Fig.3. is the framework for the temporary residence planning area.

\subsection{Proposal of a Temporary Residence Planning Method}

In order to propose a temporary residence planning method for refugees, previous planning methods were collectively analyzed and separate proposals were made for the temporary residential complex, the temporary residence, administration, and management sections.

\begin{tabular}{|c|c|c|}
\hline & \multicolumn{2}{|c|}{$\begin{array}{l}\text { Temporary Residential Planning } \\
\text { Area for Refugees }\end{array}$} \\
\hline $\begin{array}{c}\text { Temporary residential } \\
\text { complex area }\end{array}$ & \begin{tabular}{|c|} 
Temporary residential \\
space planning area
\end{tabular} & $\begin{array}{c}\text { Administration and } \\
\text { management area }\end{array}$ \\
\hline Complex location & Elevation, Section & Administrative \\
\hline Arrangement plan & Structural plan & Installation proposal \\
\hline Public facilities & Electricity equipment & Maintenance \\
\hline Infrastructure & Material plan & Proposed period \\
\hline & Interior plan & Usag \\
\hline
\end{tabular}

Fig.3. The Framework for the Temporary Residence Planning Area

Table 12. Proposal of a Planning Method for a Temporary Residential Complex

\begin{tabular}{|c|c|}
\hline $\begin{array}{l}\text { Temporary } \\
\text { Residential } \\
\text { complex }\end{array}$ & Planning method \\
\hline $\begin{array}{l}\text { 1.Complex } \\
\text { location }\end{array}$ & $\begin{array}{l}\text { (1) Place it close to a major road with adequate approach to public } \\
\text { facilities. } \\
\text { (2) Place facilities at a topography convenient for installation. } \\
\text { (3) Plans on location selection by type. }\end{array}$ \\
\hline $\begin{array}{l}2 . \\
\text { Arrangement } \\
\text { plan }\end{array}$ & $\begin{array}{l}\text { (1) Plan for the most efficient arrangement. } \\
\text { (2) Plan the distance between buildings according to the climate. } \\
\text { (3) Plan the transfer route concisely and clearly for use of relief } \\
\text { material and emergency vehicles. }\end{array}$ \\
\hline $\begin{array}{l}\text { 3. Public } \\
\text { facilities }\end{array}$ & $\begin{array}{l}\text { (1) Build public facilities of the concentration type according to } \\
\text { the characteristics and allocate the number according to the } \\
\text { number of temporary residences. }\end{array}$ \\
\hline $\begin{array}{l}\text { 4.Infrastruc- } \\
\text { ture } \\
\text { facilities }\end{array}$ & $\begin{array}{l}\text { (1) Install facilities to provide a convenient water supply. } \\
\text { (2) Arrange properly by location and site according to the } \\
\text { characteristics. }\end{array}$ \\
\hline
\end{tabular}

Table 13. Proposal of a Planning Method for a Temporary

Residence

\begin{tabular}{|c|c|}
\hline $\begin{array}{l}\text { Temporary } \\
\text { Residence }\end{array}$ & Planning method \\
\hline 1. Plan & $\begin{array}{l}\text { (1) Plan for minimal residential size. } \\
\text { (2) Separate rooms according to the minimum } \\
\text { residential needs. } \\
\text { (3) Plan according to the number of family members. } \\
\text { (4) Plan both for modularity and adaptability of space. }\end{array}$ \\
\hline $\begin{array}{l}\text { 2. Elevation } \\
\text { section } \\
\text { plan }\end{array}$ & $\begin{array}{l}\text { (1) Plan elevation according to the function. } \\
\text { (2) Plan the cross section with a rational height } \\
\text { according to mobility and the structural type. }\end{array}$ \\
\hline $\begin{array}{l}\text { 3. Structural } \\
\text { plan }\end{array}$ & $\begin{array}{l}\text { (1) Carry out the usage plan and research development by } \\
\text { dividing time into short, medium, and long periods. }\end{array}$ \\
\hline $\begin{array}{l}\text { 4. Electrical } \\
\text { Equipment } \\
\text { plan }\end{array}$ & $\begin{array}{l}\text { (1) Plan concisely according to the temporary nature of the site, } \\
\text { maintain minimal functions, and make pipe transfer and } \\
\text { replacement convenient during transfers. }\end{array}$ \\
\hline $\begin{array}{l}\text { 5. Material } \\
\text { plan }\end{array}$ & $\begin{array}{l}\text { (1) Select materials that can be easily obtained in } \\
\text { near by areas, are environmentally friendly, are easy to } \\
\text { maintain and are economical. }\end{array}$ \\
\hline $\begin{array}{l}\text { 6. Interior } \\
\text { plan }\end{array}$ & $\begin{array}{l}\text { (1) Take into account the function of an economical } \\
\text { material plan and efficiency. Plan for facilities } \\
\text { that also take into account the weak and elderly. }\end{array}$ \\
\hline $\begin{array}{l}\text { 7. Installation } \\
\text { time period }\end{array}$ & $\begin{array}{l}\text { (1) Installation should happen rapidly in a short amount of time } \\
\text { within the installment period. }\end{array}$ \\
\hline
\end{tabular}

Table 14. Proposal for a Planning Method for Administration and Management

\begin{tabular}{l|l}
\hline $\begin{array}{c}\text { Administration \& } \\
\text { Management }\end{array}$ & \multicolumn{1}{c}{ Planning method } \\
\hline $\begin{array}{c}\text { 1. Administrative } \\
\text { process }\end{array}$ & $\begin{array}{l}\text { (1) The administration and an architectural } \\
\text { planning manual should be developed. }\end{array}$ \\
$\begin{array}{l}\text { 2. Installment } \\
\text { and proposal }\end{array}$ & $\begin{array}{l}\text { 1) A management system should be } \\
\text { implemented in a short time. }\end{array}$ \\
\hline $\begin{array}{l}\text { 3. Maintenance } \\
\text { and management }\end{array}$ & $\begin{array}{l}\text { 1) Plan so that it becomes a rational and swift system for } \\
\text { the resident and official in charge of administrative } \\
\text { work - the business needs to be both collaborative and } \\
\text { professional }\end{array}$ \\
$\begin{array}{l}\text { 4. Proposal } \\
\text { period }\end{array}$ & $\begin{array}{l}\text { 1) Plan flexibly by dividing into short, medium and long } \\
\text { time periods. }\end{array}$ \\
\hline $\begin{array}{l}\text { 5. Usage plan } \\
\text { (1) Plan to reuse, (2) Plan for other. } \\
\text { 3) Plan to export for the use of relief. }\end{array}$ \\
\hline
\end{tabular}




\section{1) Temporary Residential Complex}

This study proposes a planning method appropriate for temporary residential complexes in Korea by excluding temporary residences and dividing the planning factors into the complex location, arrangement plan, public facilities, and basic facilities.

The details are shown in Table 12.

\section{2) Temporary Residences}

Temporary residences should have the characteristics of efficiency, mobility, modularity, light weight, environmentally friendly, reusability, and adaptability. The details are shown in Table 13.

3) Administration and management

In Korea, temporary residences must improve administration and management by creating a manual for the person maintaining and managing temporary residences. The details are shown in Table 14.

\section{Conclusion}

This study proposed a planning method for temporary residences in Korea, and has presented its conclusion by integrating these items.

First, the characteristics of temporary residences have been deduced along with the physical components through documentary research, and the contents can be separated according to the residential complex and residential type.

Second, the administration and management has been added and analyzed through a comparison of the on-site research and interviews of temporary residences in Korea and Japan.

Third, by reorganizing the planning items of temporary residences that were deduced from documents and on-site research, the planning items of temporary residences have been derived through surveys and interviews of staff members. The planning method of complex locations should consider convenient access to major roads and should be made either as a group type or an individual type. For the arrangement plan, the use of outside space must increase, allowing for efficient arrangement following the module method as the most efficient arrangement form, and the transfer route must be planned concisely and clearly. According to the plan on public facilities, an adequate number should be planned according to the number of temporary residences. Planning the infrastructure facilities that allow for an uninterrupted supply of water should be installed. For the spatial plan of temporary residences, the floor plan must have a separation of rooms according to the minimal residence size and function.

The spatial plan should also be appropriate according to the number of family members, and it should be a plan with adaptability. For the structural plan, the structure types of temporary residences are divided into the fixed-type and portable-type. The portable type fits the situation in Korea, and further research and development must be conducted in this area. For the planning of the electrical equipment and materials, current cooling and heating of temporary residences must be taken into account, and plans must allow for continuous maintenance and management. The material plan must also be environmentally friendly, easy to maintain and manage, and economical. The interior planning must be conducted according to allowances for the weak and elderly, along with an economic material plan.

A manual needs to be created to facilitate residence selection and arrangement for temporary residences. This manual must include contents on the administration and management of temporary residences. Also, concerning the installment and planning items, in terms of maintenance and management, a management system must be planned that can be installed in a short period of time. Furthermore, a flexible plan must be drawn up to fit the local reality after classifying the planning items period into short, medium and long time periods. Additionally, the usage plan of temporary residences must be planned so that the residences can be utilized for other purposes or be recycled.

This study can be evaluated as a study on the planning method of temporary residences for refugees. However, since an in-depth study on a synthetic application plan that includes a detailed planning guide, the systematic aspect of temporary residences, and the development of an administrative program has not yet been carried out, a more systematic and indepth research is proposed for future studies.

\section{References}

1) Garcia Belen, (2000) Earthquake Architecture: new construction techniques for earthquake disaster prevention, LOFT and HBI.

2) Brenda Vale, (1995) Prefabs- a history of the UK Temporary Housing Programme, E\&FN Spon.

3) Allison Arieff and Bryan Burkhart, (2002) PRE FAB, Gibbs Smith.

4) Robert Kronenburg, (1995) Houses in Motion, Academy Edition.

5) UNHCR, (2003) Minimum Standards in shelter, settlement and non-food item.

\section{Footnotes}

"Disasters" according to the South Korean Disaster and Safety Management Law refers to: A. Typhoon, flood, storm, tidal wave, hail, drought, earthquake, dust storm, red tide, or other related calamities that occur due to the forces of nature. B. Fire, collapse, explosion, car accident, chemical accident, environmental contamination or other similar accidents that produce damage that is in excess of the size fixed by the Presidential decree, and also refers to the paralysis of state-based systems including energy, traffic, finance, medical service, water service, and the spread of infectious diseases.

2 "Calamities" in the South Korean Agriculture and Fishery Calamities Measure Law refer to agricultural calamities and fishing calamities.

3 Lee Han-Na, Housing Methodology for Disaster Refugees, Proceeding of 2004 Autumn Conference, Architectural Institute of Korea, Vol. 24, No. 2, October 2004 pp. 144.

4 World Health Organization.

5 UNHCR (Office of the United Nations High Commissioner for Refugees). 